\title{
THE JITNEY BUS AND ITS FUTURE ${ }^{1}$
}

BY WILLIAM J, LOCKE

San Francisco

$\mathrm{O}^{\mathrm{N}}$ $\mathrm{N}$ a certain morning about nine months ago the residents of one of our Pacific coast cities might have observed an automobile running along the main street bearing a sign announcing that passengers would be carried between certain designated points in the city for the small sum of five cents. On the following morning, instead of one machine they might have seen half a dozen or more, and within a few days following thereafter their numbers were multiplied many times over. Before a month had passed the increase had caused such a congestion in the streets as sorely to try the skill and patience of the traffic police, while for pedestrians, the mere crossing of a main street had become a most hazardous undertaking.

In such a fashion did the "jitney bus" make its introduction into municipal life, bringing in its train many new problems to worry the municipal legislative mind. The nature of the idea was such that it was bound to spread rapidly and before many weeks had passed the "jitney" had made its appearance in nearly all the larger cities of this country and Canada. On March 15, 1915, Andrew Linn Bostwick, municipal librarian of St. Louis. Mo., in a report on the jitney omnibus and its regulation, stated that jitneys had been introduced in over thirty cities ranging in size from 750,000 downwards. It is quite certain, however, that this report did not include the small cities, as by that time the number in which the jitney had made its appearance exceeded that figure in California alone, and at this writing there is scarcely a city of any size in this country where the jitney bus is not operated.

For a while, after they were first introduced, many people looked upon the "jitney" as merely a fad, believing the idea would prove to be impracticable from an economical standpoint. Instead, however, the number of jitneys continued to increase, and the increase in numbers was met apparently by a corresponding increase in patronage. Later the passage of ordinances imposing a license tax and requiring an indemnity bond resulted in many jitney operators quitting the business,

\footnotetext{
${ }^{1}$ In the April issue (vol. iii, p. 290), William Richard Littleton discusses the motor bus and its development. He covers certain points that are also covered by Mr. Locke, but notwithstanding this, we are publishing this second article because it approaches the whole question from a different standpoint and is written by one identified with the section in which the use of the jitney bus has had its conception in this country. Mr. Locke is assistant secretary and counsel of the League of California Municipalities.
} 
while others gave it up on finding the profits under their expectations. Nevertheless, a sufficient number has continued in the business to indicate that the jitney has come to stay.

A Los Angeles writer has summed up the jitney situation in an interesting manner. In his opinion, the "jitney bus" is a business anomalya business failure that is bound to stay; a failure because only rarely can the operator secure enough passengers in a day to pay the operating expense and repair costs on his car, make an adequate allowance for depreciation and pay himself a reasonable wage on a five cent fare. This is admitted by many of the drivers, so it is claimed. What they are really doing is selling the residue value in old cars to the public in nickel installments, living on their cars, if they are their own, or making a bare living from a secondhand dealer, until they can get some kind of a steady job. The men in the automobile trade point out that this kind of people and this kind of cars and conditions will be found in some cities all the time, and that as fast as one goes out of the jitney business his place will be taken by another.

There is no doubt but that the foregoing summary of the situation is correct in a large measure, but that it is not entirely so is evidenced by the fact that companies are being organized in many parts of the country to engage in this new method of transportation. In connection with this phase of the subject, the recent report of the American electric railway association, following a nation-wide and painstaking investigation, will prove interesting, if not instructive. The report says:

Considering the case of the company that purchases machines and treats the whole matter as a business proposition, we reach a different conclusion.

The costs varying with the mileage will be placed at five-eighths of a cent per mile. Other operating expenses to be considered are insurance of all kinds, including injuries and damages, $\$ 200$ a year; cleaning, inspection and housing, say $\$ 100$ per year; wages for driver, a minimum of $\$ 2.00$ a day, or $\$ 700$ a year; management, 75 cents a mile on the basis of 75 miles a day for 350 days, $\$ 195$ per car per year. This figure is based on the expense of supervision of one of the largest taxicab companies and probably could not be equaled by a company operating less than 300 cars.

The above operating expenses may be summarized as five-eighths of a cent per car mile plus $\$ 1,195$ per year. To these must be added $\$ 240$ for interest and depreciation, and about $\$ 5$ each for state registration, personal property tax, and public vehicle license. The total thus is $\$ 1,450$ a year plus five-eighths of a cent per car mile. This includes 8 per cent return on the investment in cars (there will be little other investment necessary) and excluding the return we find the expenses to be $\$ 4.05$ a day plus five-eighths of a cent a mile. Depreciation is based on 5,000 miles a year and would likely be exceeded, inasmuch as 75 miles a day or 25,000 a year probably will be run. The depreciation estimate of the Ford Company is $\$ 200$ for 5,000 miles or four cents a mile. 
There is no longer any attempt to deny the fact that the "jitney bus" has had a serious effect on the business of the street railway companies. In Los Angeles, for instance, it has been estimated that the loss amounts to $\$ 2,000$ per day, while in Winnipeg, street railroad traffic has decreased to such an extent since the advent of the jitneys as to necessitate a reduction in the number of street cars, a reorganization of routes, and a contemplated reduction in staff. Reports from Vancouver for the first. quarter of the year indicate that the percentage of the gross receipts which the city will receive from the railway companies for 1915 will be from $\$ 30,000$ to $\$ 35,000$ less than last year, due to the operation of 350 jitney buses which are now carrying a majority of the passengers who formerly rode in street cars. Increased patronage of the jitneys in Memphis has necessitated a retrenchment on the part of the Memphis street car companies, involving a reduction of 30 per cent in the shop force and a cut of from ten to twenty per cent in the salaries of the remaining employes. Similar retrenchments by the street car companies are reported from Bridegport, Conn., and Grand Rapids, Mich. The San Francisco-Oakland terminal railroads, according to the company's. officials, have been losing $\$ 500$ per day in fares since the advent of the jitney. In Seattle, one company claims a loss of $\$ 2,450$ daily, while another estimates that it will carry fewer passengers this year by 21,000 ,000 than it did in 1914, if the jitney competition continues.

One of the principal advantages claimed for the jitney is the fact that. the average rate of speed is greater than that of the street car. It cannot. be denied that this is an important advantage, which is due to a number of things. In the first place, the jitney carries but a few passengers as compared with the street car and consequently there are fewer stops to be made. Again, should the jitney come upon a slower moving vehicle or some obstacle, it can pass around it, whereas the street car, being confined to its track, must reduce its speed to that of the slower vehicle or wait. until the obstacle has been removed.

Notwithstanding the short time since the advent of the jitney, much progress has been made in improving the design and appearance of these new vehicles of transportation. For example, the one used in Winnipeg is quite elaborate and has become very popular. The body inside is 13 feet long by $5 \frac{1}{2}$ feet in width. It is protected with storm curtains which may be removed when the weather is good. It has the appearance of an open touring car. Pneumatic tires are used on the forward wheels and solid tires on the rear. The car accommodates eighteen passengers and has spring seats upholstered in leather, which makes. very comfortable riding. It is lighted at night by two electric domes in the ceiling. Push button signals are provided which are connected with a buzzer near the driver's seat. At night a green light indicates vacant seats, while a red light is shown when the car is filled. 
In San Francisco, a company has been organized to operate a line of motor buses, which are to be constructed after the style of an Irish jaunting car, with two rows of seats running lengthwise, back to back, and an aisle between them. In such a car one may step up into a seat directly from the street and vice versa, without being obliged to climb over the feet of other passengers. Another advantage of this form of construction lies in the fact that the car may be filled or emptied almost immediately. Transparent roller curtains are to be provided for bad weather.

One of the first companies organized to undertake the jitney business was the Jitney service company of Odgen, Utah, which now operates three lines. In Peoria, Ill., the business has been undertaken by an old established concern of which one of the city aldermen is a member. The business in St. Louis, Mo., is handled by the Motor service company, which carries about two thousand passengers a day.

As the jitney continued to increase in numbers, a demand arose from various quarters for more stringent regulation of the business and, with the street railway companies in the lead, petitions were presented to the municipal and state authorities asking for the enactment of legislation to this effect. The Massachusetts street railway association, comprising nearly all of the street railroads in the state, had a bill introduced in the legislature requiring that all corporations formed to transport passengers in automobiles having a seating capacity of eight or more, should have a capital stock of not less than $\$ 10,000$ for each of the total number of passengers that might be carried in the largest car of the corporation. The bill further provided that all private individuals in the business should file a bond of $\$ 500$ for each passenger seat, or according to the capacity of the car. As a typical illustration of railroad opposition, it was charged that a company owning and operating the electric railways running between Los Angeles and Pasadena, was instrumental in preventing the Pacific motor bus company from securing permission to operate over a very desirable route between the cities mentioned.

However, opposition was not confined to the street railroad companies. In many instances, their employes, believing their jobs in jeopardy, made vigorous demands for more stringent regulations of the jitney. In Des Moines, for instance, a delegation from the carmen's union was appointed to watch the activities of the council during the time the jitney bus ordinance was under consideration.

There is a wide difference in the amount of license tax imposed on the jitney by various municipalities throughout the country; for example, the annual tax of Joplin, Mo., ranges from $\$ 10$ for a five-passenger car to $\$ 40$ for one carrying 26 passengers or over; in Oklahoma City, the annual tax runs from $\$ 50$ to $\$ 150$, according to capacity; in Boise from $\$ 75$ to $\$ 150$; in Spokane, $\$ 2.50$ for the original license and $\$ 1$ for its removal; in Pasa- 
dena, $\$ 50$ to $\$ 75$, according to capacity; in Des Moines, $\$ 15$ to $\$ 35$, according to seating capacity; in Syracuse, $\$ 75$ to $\$ 150$, according to capacity; in Fort Worth from $\$ 10$ to $\$ 30$; in Oakland all pay $\$ 60$, and in San Antonio the license tax is $\$ 35$, and $\$ 3.50$ extra for each seat over seven.

It is universally conceded that the principal factor in determining the success or failure of the jitney business is the length of route traveled. The American electric railway association, in the report aforementioned, reached the conclusion that the jitney business will be confined to the short hauls, for the reason that the long trips will not pay. This conclusion has proved to be correct and as a result jitneys are taking the cream of the business, leaving the railway companies nothing but skimmed milk. In San Francisco, for example, while the street rail'way companies are required to carry passengers more than five miles across the peninsula for five cents, the jitneys operate only for one-half that distance.

In California, as in many other states, the street railway companies are obliged to pave that portion of the street lying between their tracks and two feet on either side, and they are calling public attention to the fact that not only are they obliged to submit to the competition of the jitney, but are also compelled to construct and maintain the pavement upon which their competitors operate. It is evident that municipal regulation of the jitney will be obliged to cover the distance to be traveled as well as the route. Otherwise, many of the street car companies will be forced into bankruptcy. Up to the present time, the principal extent of the regulation has been limited to protecting the public from careless or irresponsible drivers, overcrowding, indignities to female passengers, arbitrary change of routes and liability in case of accident. Other regulations cover the questions of route, the territory to be served and the seating capacity of the car. Many ordinances authorize the city council to refuse a license if the territory is already served. In Victoria the route terminates in a district instead of a street, and passengers may be taken to their homes if living within the district.

The legal status of the jitney business has not been clearly determined. In Washington the state public service commission recently decided that the jitneys are common carriers and subject to regulation by the commission. In California, however, the state commission has decided that it has no jurisdiction. In Oregon, the legislature refused to put the jitney business under control of the state commission.

The advent of the jitney has had a disastrous effect on the safety of street travel. In Los Angeles, according to statistics, a sharp increase in the number of accidents was observed coincident with the introduction of this method of transportation. In July, August and September of 1914, street accidents averaged slightly less than 400; in October, the jitneys began to appear, and street accidents ran up to 463 , while in 
November they reached a total of 601 . The number of accidents has increased to such an alarming extent wherever the jitney has been introduced, that the Safety-first federation of America has taken the matter up for special attention and, according to reports, plans for the regulation of the jitney, national in scope, are being prepared by the executive committee of that organization.

Practically all ordinances that have been adopted on the subject of regulation require an indemnity bond ranging from $\$ 5,000$ to $\$ 15,000$, although in Washington, D. C., satisfactory assurances of responsibility are all that is required in addition to the annual license fee of $\$ 6$. A new ordinance of Syracuse, N. Y., imposes a liability bond of $\$ 5,000$ for injuries received by one person and $\$ 15,000$ for injuries received by more than one person in a single accident. In Des Moines, vigorous: objection was made by the jitney operators to a $\$ 2,000$ bond, their attorney denouncing such a bond as prohibitory and discriminatory, and calling attention to the fact that no bond was required in many other cases where the nature of the business is hazardous to the public. In Philadelphia, two rival organizations of the jitney operators divided on the question of an indemnity bond, one favoring a $\$ 2,500$ bond and the other attacking it on constitutional grounds. In Minneapolis, the Times took up the cause of the jitney men on the bond question and asked why the owners of private cars were not required to give a bond. However, most of the municipal ordinances throughout the country require an indemnity bond ranging from $\$ 5,000$ for injury to or death of one person, to $\$ 10,000$ for injury to or death of more than one person, while others require an additional $\$ 1,000$ bond for possible damage to property.

Should the jitney bus be operated under a permit or a franchise? This is one of the most important questions raised in connection with its operation. The city attorney of San Diego recently held that in his opinion a municipality might prohibit the running of jitneys unless they secured a franchise. Others are of the opinion that a franchise cannot be required. Bouvier's "Law Dictionary" defines a franchise to be "a special privilege conferred by government on individuals, and which does not belong to the citizens of the country by common right," whereas another well-known authority declares that "whatever is of large public concern, so that the want of regulation and control will injuriously affect the public in its general interests, may be the subject. of a franchise." This last definition was laid down by the Supreme Court of New York in the case of People vs. Leow. ${ }^{2}$ In this connection, attention is called to the fact that the Fifth avenue coach line in New York City operated under a franchise granted directly by the state in 1886.

${ }^{2}$ Vol. 44, N. Y. Supp., p. 43. 
In Denver, and also in San Antonio, no person or corporation may operate jitneys without a franchise. An act passed by the California legislature prohibited any person or corporation operating a jitney bus without first receiving a franchise or permit; however, it was not approved by the governor.

Probably the most important distinction between a permit and a franchise is the fact that the former is revocable whereas the latter is not. This being the case, it is likely that the future will see the jitney bus operating under a franchise instead of a mere permit, as sound business principles will restrain capital from investing in an enterprise that depends upon the whim of a city council for the continuance of its existence. Again, operation under a permit necessitates an indemnity bond which is not only expensive and unsatisfactory, but also objectionable for other reasons. The operation of jitney buses by organized companies under a franchise would have many advantages. For example, provision could be made for covering the long routes as well as the shorter and more favorable ones; also, arrangements for transferring passengers from one line to another. The grant of a franchise could be made contingent upon the municipality receiving a share of the profits. Considered in all its phases, the jitney appears to present many attractive inducements for municipal ownership and operation.

There is every indication that the "jitney bus" is the forerunner of the trackless car, something that the world has been looking for for many years. If such is the fact, and it means that the time has arrived when vehicles may be run over a smooth pavement by their own motive power as cheaply as the ordinary trolley car running on a track, then there is certainly cause for congratulation. The greatest single item of expense is the tires, and the invention of a satisfactory substitute for the pneumatic tire would remove absolutely any question as to the success of this new means of transportation.

The elimination of the car track would give our streets a much more pleasing appearance and remove a source of more or less danger, all of which and much more may be said by way of argument for abolition of the poles and overhead wires. The trackless car is speedy and comparatively noiseless. In case of a breakdown it may be run to one side of the street temporarily and the passengers transferred to another car. The whole line would not be put out of commission in any event, and there would be no such thing as a blockade. Again, in case of congestion some cars could be transferred for the time being to adjacent parallel streets. Last but not least, among the many advantages would be the elimination of noise, thereby conducing to better health and to the more peaceful enjoyment of life. 